\title{
Scientific Research and New Uses for Coal*
}

$\mathrm{I}^{\mathrm{T}}$

is frequently stated that the lessened demand for coal is due partly to its more economical use, partly to the great extension in the use of gas and electricity, and partly to the harnessing of waterpower. Nothing could be more erroneous. The more economical use of a commodity, as Prof. Jevons has shown, does not, as is commonly supposed, lead to a restriction in its consumption. Every economy in the production and consumption of an essential commodity, if duly reflected in its selling price, will increase the public demand. That is emphatically so in the case of fuel. People do not keep windows closed in Great Britain because they prefer stuffiness to air, but for warmth. Our climatic conditions are such that for two thirds of the year there is a large unsatisfied demand for fuel in Great Britain.

As with fuel, cheapening the cost of power leads to its more extensive consumption. Take the case of Italy. It was stated when Italy set about developing her considerable latent resources of water-power, owing to the high price of coal in 1918-20 (coal was sold in Genoa at $£ 7$ 10s. 0d. per ton after the Armistice), that the importation of coal would decrease materially.

The reverse has proved to be the case, as the following figures show :

\begin{tabular}{c|c|c}
\hline Year & $\begin{array}{c}\text { Imports of Coal and Coke : } \\
\text { tons }\end{array}$ & $\begin{array}{c}\text { Home production : } \\
\text { tons }\end{array}$ \\
\hline 1913 & $10,659,890$ & 266,552 \\
1919 & $6,093,776$ & $2,368,068$ \\
1929 & $14,272,147$ & 945,000 \\
1931 & $10,911,657$ & 590,701 \\
\hline
\end{tabular}

It is fifteen years since Sir George Beilby, Sir Charles Parsons, myself, and Mr.-later Sir-Richard Thelfall signed the Report on Gas Standards, in which we stated that "The national interests will best be served by that policy which will promote the widest adoption of scientific methods for the preparation and use of fuel". There are prospective developments - what are commonly termed 'new uses' for coal--which are under constant and intensive examination, though it cannot yet be said positively -with one possible exception - that they are able to stand on their own feet. The prospective developments I have in mind are :

(1) The hydrogenation process.

(2) Low-temperature carbonisation of coal.

(3) The use of gas in transport in place of petrol.

I refer, in particular, to the turning of coal into oil, namely, the wider application of the low-temperature carbonisation of coal, with the consequent production of tar suitable for burning under boilers, or the hydrogenation of this resultant tar in order to secure a home supply of petrol of the first quality ; or, alternativeiy, the treatment of the tar so as to render it available for use in Diesel engines. I prefer to regard the hydrogenation process as, at present, applicable rather to the treatment of tar than to the direct treatment of coal.

In view of the increasing use of smokeless semicoke resulting from the low-temperature distillation of suitable coals, it is worth while to pause for a few minutes and consider what would be the result of its substitution on the grand scale for raw coal in

* From the presidential address to the Institution of Civil Engineers, delivered by Sir Richard Redmayne on November 6. our homes. Great Britain is at present practically dependent upon foreign countries for its supply of fuel-oil and of petrol, and from this point of view alone it would appear that the development of a home source is of great importance. There is also the fact that were the low-temperature carbonisation of coal to become established, it would undoubtedly contribute to an increase in the production of coal and to greater employment in many directions.

As indicative of the possible bearing that the application of these methods may have upon the coal industry, I would point to the domestic consumption of raw coal, which amounts to about 35 million tons per annum. If the whole of this demand were met by the semi-coke produced by low-temperature carbonisation, there would result :

(1) An augmentation in the national output of coal amounting to about 12 million tons per annum.

(2) The production annually of the following alternative products : (a) 2 million tons of tar-oil for fuel purposes; (b) $1 \frac{1}{2}$ million tons of Diesel engine oil ; (c) 358 million gallons of petrol.

(3) The production annually of 100 million gallons of petrol by stripping the gas.

(4) An increase in the employment of miners of $35,000-45,000$ men, with a consequent annual saving in unemployment benefit.

(5) Increased employment at low-temperature carbonisation works.

The quantity of fuel-oil obtained would be more than sufficient to meet the peace requirements of the Royal Navy ; or, if subjected to full hydrogenation, 358 million gallons of petrol would be produced which, with the 100 million gallons obtained from the gas, would amount to about half the quantity imported during 1932.

Even if it were not found practicable to carbonise the whole of the 35 million tons of domestic fuel for the above purposes, owing possibly to the competition that would arise due to the increasing use of electricity and gas for domestic purposes, it is useful to record that there should still be forthcoming the following advantages :-(1) A considerable augmentation in the output of coal due to the increased demand for semi-coke, electricity and gas. (2) The production of at least enough tar for fuel purposes, or, alternatively, of Diesel oil or petrol for power purposes, to enable Great Britain to have a reasonable home source of these products, and one capable of expansion in times of national emergency. (3) An increase in employment of workers.

The semi-coke, as is well known, produces a more efficient open fire than raw coal, with the definite added advantage that it is smokeless. In the words of Sir Frank Smith in his Norman Lockyer lecture of last year, "It should not be forgotten that the damage done by smoke to the nation's health and to our buildings must be reckoned in tens of millions of pounds per annum; smokeless fuels, including gas and electric power, show us the way out."

The low-temperature distillation process seems to be in a fair way to becoming a stable industry, for the year 1929 saw the establishment in England of the first distillation plant in the world devoted solely to the distillation and fractionisation of low-temperature coal-oil. In 1930 occurred the first full-scale experiments with aeroplanes flying on coal-petrol, and in 1932, for the first time, vessels of the British Navy 
put to sea fuelled only with oil made from British coal. 1933 saw a number of home-defence aircraft, flying daily, actuated by coal-petrol alone, and also, for the first time, large cargoes of low-temperature coal-oil distillates were shipped to foreign countries.

Another possible method of increasing the consumption of coal is in the larger production of gas owing to its use in the compressed form for motor transport. A committee which has been considering this matter for many months past recently published the results of the experimental work so far completed. From those results it is quite evident that the technical problems involved in the substitution of gas for liquid fuel have been solved. For more than a year, such vehicles have been running continuously and successfully upon compressed gas. It has been found that 250 cubic feet of gas of a calorific value of 500 B.Th.U. per cubic foot (that is, $1 \frac{1}{4}$ therm) is equivalent to a gallon of motor spirit.

In a report of a series of exhaustive tests made with a lorry owned by the Whitwood Chemical Company, Ltd., of Normanton, and extending to about 670 miles, it is stated that the consumption of fuel was 9,400 cubic feet of gas and 27 gallons of low-grade oil. Based on the data obtained from this trial, it is possible to give the comparative costs of petrol, oil and enriched gas, as follows :-

Total All-in Costs per Mile for Varying Mileages per Annum

\begin{tabular}{c|c|c|c}
\hline Miles per annum & Petrol (pence) & Oil (pence) & Gas (pence) \\
\hline 5,000 & $19 \cdot 54$ & $19 \cdot 54$ & $18 \cdot 41$ \\
10,000 & $12 \cdot 18$ & $11 \cdot 62$ & $11 \cdot 05$ \\
15,000 & $9 \cdot 73$ & $8 \cdot 98$ & $8 \cdot 60$ \\
20,000 & $8 \cdot 50$ & $7 \cdot 66$ & $7 \cdot 37$ \\
30,000 & $7 \cdot 27$ & $6 \cdot 34$ & $6 \cdot 14$ \\
40,000 & $6 \cdot 66$ & $5 \cdot 68$ & $5 \cdot 53$ \\
50,000 & $6 \cdot 29$ & $5 \cdot 28$ & $5 \cdot 16$
\end{tabular}

Developments in the use of producer gas, electricity, and steam for motor transport have also made great strides. A strong case could be made out for the sole use in our large towns of electric taxis, with the beneficial results of cessation of noise and deleterious fumes, for it is possible now to run a Morrison electric car for 40 miles without recharging, doing $2 \frac{1}{2}$ miles per unit of electricity. Each such vehicle daily at work means in electricity consumption alone 3 days' work per annum to a miner. For long-distance, heavy-goods transport, the steam-driven lorry, year in year out, is probably the cheapest motor for the purpose on the road.

\section{University and Educational Intelligence}

CAMbridge.-At the Congregation of the Senate on November 17, a grace will be submitted approving the conferment of M.A. honoris causa upon Prof. William P. Wynne, emeritus professor of chemistry in the University of Sheffield, who is engaged on research work at Cambridge.

The Cavendish Professor of Experimental Physics gives notice that the Clerk Maxwell scholarship will become vacant on December 25. Candidates are requested to send in their applications to Lord Rutherford at the Cavendish Laboratory on or before December 1.

The annual meeting of the Science Masters' Association will be held at Oxford on January 1-4, under the presidency of Dr. N. V. Sidgwick, reader in chemistry in the University. The following lectures will be given during the meeting : C. N. Hinshelwood, "Some Aspects of Modern Physical Chemistry"; Prof. H. H. Plaskett, "The Physics of Astronomical Vacua"; R. B. Fisher, "Tissue Respiration"; Dr. W. O. James, "Plant Respiration" ; Prof. J. S. E. Townsend, "Ionisation by Collision"; Prof. R. Robinson, "The New Aspect of the Elementary Theory of Organic Chemistry"; Dr. K. J. Franklin, "X-Ray Photography of the Circulation of the Blood" (with cinematograph films). A discussion on scholarship examinations will also be held. Further information can be obtained from Mr. H. G. Lambert, Shirley Corner, Boden Road, Hall Green, Birmingham.

THe Battersea Polytechnic's report on the session 1933-34 shows a total enrolment of 3,156, a slightly larger number than in the preceding year. About one sixth of the students attended full-time day courses, chiefly in domestic science (250), engineering (115) and hygiene (47), the remaining five-sixths being evening class students, chiefly of engineering $(2,231)$, chemistry $(1,009)$, domestic science $(758)$, hygiene (742), mathematics (586) and physics (578). In view of the ever-increasing use of electric power for domestic purposes, it is surprising that the classes in 'electrical housecraft' were attended by only 8 students. This year the Electrical Association for Women is lending its kitchen for training purposes. A table of occupations followed by students shows : clerical 608, engineering 533, chemistry and physics 279 , sanitary inspectors, etc. 180, teaching 166, domestic service 102, dressmaking, etc. 53, food production 51 , shop-assistants, etc. 38, other occupations 137 , students only 579 , retired and unoccupied 250. A 'follow-up' of former students (mainly daystudents) shows the following numbers of posts obtained during the past ten years: 878 posts requiring domestic science qualifications, 327 as sanitary inspectors, etc., 252 as engineers, 206 as chemists, scientific assistants, science teachers, etc., 79 as art and handicraft teachers or practitioners. A students' union was instituted during the past year.

Adult education is developing and expanding in the United States of America as a result of certain phases of the President's "New Deal". In the May issue of School Life, devoted chiefly to summer schools and holiday tasks, is published an article on schools for workers, giving some account of how the Federal Government is co-operating with organisers of workers' educational associations and trade unions in experimental courses preparatory to launching a campaign for a wide extension of adult education classes. Among the subjects studied in these classes for workers are : the economic position of the United States, the labour movement abroad, English and public speaking. The teaching is on the lines of the regular summer-school courses. An editorial forecast assigns to universities of the future the task of providing at minimum costs for summer holiday activities combining learning and recreation for old and young in camps in national parks. At present, the summer-session programmes are too generally limited to meeting the demands of students who want to work for more 'credits'. The same issue quotes a recent appreciation of American educational methods by Prof. A. Einstein, giving first place to the negative virtue of non-interference with personal initiative, independence and joy of living and the urge for knowledge. 